\title{
Pengaruh Kurikulum Filosofi Sepak Bola Indonesia (Filanesia) Terhadap Kemampuan Dribbling dan Passing Di Sekolah Sepak Bola Putra Mulyoharjo (Ps Puma) U-17 Kabupaten Jepara
}

\author{
Riki Candra Setiawan \\ Universitas PGRI Semarang, 50125, Indonesia \\ * Riki Candra Setiawan. E-mail: coachrickycandra@gmail.com
}

\begin{abstract}
This research is motivated by the current soccer game, players are required to be able to control the ball better, so that the chances of creating goals are greater. Techniques in soccer games that are often used and the most important techniques are kicking the ball (Passing) and dribbling the ball (Dribbling). combined with the philosophy of Indonesian football (filanesia) which has been made in such a way and designed according to the characteristics of Indonesian players. This research is a descriptive quantitative research. This research was conducted in several steps, namely the pretest and posttest which will be carried out in accordance with the training program that has been made to combine the philosophy of Indonesian football with basic soccer techniques, namely Passing and Dribbling, which is carried out at the Mulyoharjo Men's Football School, Jepara Regency, aged 17 years. Divided into 2 experimental groups. In 1 filanesian group there were 10 children and group 2 Controlling had 10 children. The results showed that there was a significant effect of the application of the philanesian training model on Dribbling and Passing at the Putra Mulyoharjo Football School. Data analysis using SPSS 21. The results of the data analysis test using the Paired Simple T Test and Independent T Test, namely the results of the sig value. (2-tailed) of 0.001 in the Passing experimental group 1 Filanesia and the sig. (2-tailed) of 0.000 in the Passing experiment 2 Controlling group. Meanwhile, in the Dribbling Test, it is known that the sig. (2-tailed) of 0.000 in the Dribbling experimental group 1 Filanesia and the sig. (2-tailed) of 0.000 in the Dribbling Experiment 2 Controlling group, it can be concluded that there is a real difference.
\end{abstract}

Keywords: Dribbling, Passing, Philosophy of Indonesian football

\begin{abstract}
Abstrak
Penelitian ini dilatar belakangi oleh permainan sepak bola masa kini pemain dituntut untuk dapat menguasai bola lebih baik,sehingga peluang menciptakan Gol lebih besar teknik dalam permainan sepakbola yang sering digunakan dan merupakan teknik yang paling penting adalah menendang bola (Passing) serta menggiring bola (Dribbling) di kombinasikan dengan filisofi sepak bola Indonesia (filanesia) yang sudah dibuat sedemikian rupa dan dirancang sesuai karakteristik pemain indonesia. Penelitian ini merupakan penelitian Kuantitatif Deskriptif. Penelitian ini dilakukan dengan beberapa langkah, yaitu dengan Pretest dan Posttest yang akan dilakukan sesuai dengan program latihan yang telah dibuat untuk mengkombinasikan Filosofi Sepak Bola Indonesia dengan tehnik dasar sepak bola yaitu Passing dan Dribbling dilakukan di Sekolah Sepak Bola Putra Mulyoharjo Kabupaten Jepara Usia 17 Tahun. Dibagi menjadi 2 kelompok Eksperimen. 1 kelompok filanesia terdapat 10 anak dan kelompok 2 Controlling terdapat 10 anak. Hasil penelitian terdapat pengaruh signifikan penerapan model latihan filanesia terhadap Dribbling dan Passing di Sekolah Sepak Bola Putra Mulyoharjo. Analisis data dengan menggunakan SPSS 21. Hasil Penelitian dari test analisa data dengan menggunaikan Paired Simple T Test dan Independent $\mathrm{T}$ Test,yaitu dengan hasil nilai sig. (2-tailed) sebesar 0,001 pada kelompok Passing eksperimen 1 Filanesia dan nilai sig. (2-tailed) sebesar 0,000 pada kelompok Passing eksperimen 2 Controlling. Sedangkan Pada Tes Dribbling diketahui bahwa nilai sig. (2-tailed) sebesar 0,000 pada kelompok Dribbling eksperimen 1 Filanesia dan nilai sig. (2-tailed) sebesar 0,000 pada kelompok Dribbling eksperimen 2 Controlling maka dapat disimpulkan bahwa terdapat perbedaan yang nyata.
\end{abstract}

Kata kunci: Dribbling,Passing,Filosofi sepakbola Indonesia 


\section{PENDAHULUAN}

Keterampilan Passing dan Dribbling penting dalam menunjang sebuah tim dalam penerapan taktik membangun sebuah serangan kedaearah lawan dalam permainan sepak bola. Sejalan dengan penelitian Sporis dkk. (2010) bahwa dalam situasi permainan, perubahan arah dapat dimulai dengan mengejar atau menghindari lawan serta bereaksi terhadap gerakan bola

Filanesia Suatu Pengembangan kurikulum sepakbola di indonesia yang menjadi pondasi permainan sepakbola indonesia. Kondisi kultur-geografis, sosiologis serta kelebihan-kelebihan pemain Indonesia menjadi pertimbangan tersendiri. Kondisi geografis Indonesia yang terletak di khatulistiwa menjadikan negara kita beriklim tropis. Untuk itu diperlukan cara bermain yang dikembangkan sesuai kondisi tersebut. Nilai-nilai kebersamaan yang menjadi DNA rakyat Indonesia pun dipertimbangkan. Pertimbangan berikutnya yakni kelebihan-kelebihan pemain Indonesia. Dengan rata-rata postur sedang, pemain kita dianugerahi dengan kecepatan dan kelincahan mumpuni. Pemain Indonesia memiliki keunggulan pada sprint jarak pendek.

Dari hasil pengamatan dan wawancara dengan pelatih pusat SSB PUMA yang dilakukan peneliti pada tanggal 25 Desember 2020, masih banyak siswa KU-17 tahun yang belum tepat melakukan Passing dan Dribbling. Hal ini bisa berdampak Negatif pada saat tim bermain. Sehingga penulis berkeinginan untuk meningkatkan akurasi Passing dan Dribbling siswa SSB tersebut menjadi labih baik sesuai dengan apa yang diharapkan oleh siswa dan pelatih. Dan tidak lupa pula untuk mendukung latihan tersebut.

Dari uraian diatas maka perlu dilakukan penelitian tentang pengaruh kurikulum filosofi sepak bola Indonesia terhadap kemampuan Passing dan Dribbling Di sekolah Sepak bola Putra Mulyoharjo Kabupaten Jepara.

\section{METODE}

Desain penelitian yang digunakan dalam penelitian ini yaitu dengan menggunakan Two Group Pretest-Posttest Design . Subyek pada penelitian ini murid SSB Putra Mulyoharjo Usia 17 Tahun yang berjumlah 20 orang. Dibagi menjadi 2 kelompok dengan kelompok 1 Eksperimen Filanesia berjumlah 10 anak dengan kemampuan tehnik dasar sepakbola sedang menurut pelatih dan kelompok 2 Eksperimen berjumlah 10 anak dengan kemampuan tehnik dasar sepakbola Baik. Teknik pengambilan sampel penelitian menggunakan teknik Purposive Sample. Waktu pelaksanaan penelitian dalam jangka waktu dua bulan yaitu dari awal bulan Januari sampai awal Maret 2021. Instrumen pada penelitian ini yaitu tes ketrampilan akurasi Passing dan Dribbling. Analisa data menggunakan uji korelasi Paired TTest dan Independent T-Test SPSS 21.

\section{HASIL DAN PEMBAHASAN}

Sebanyak 20 anak telah melakukan tes ketrampilan Passing dan Dribbling dan hasil Analisa Data 
Pengaruh Kurikulum Filosofi Sepak Bola Indonesia (Filanesia) Terhadap Kemampuan Dribbling Dan Passing Di Sekolah Sepak Bola Putra Mulyoharjo (Ps Puma) U-17 Kabupaten Jepara. Riki Candra setiawan

bisa dilihat pada table 1 dan 2 .

Table 1. Passing kelompok 1

\begin{tabular}{c|c|c}
\hline Kategori & Frekuensi & Presentase \\
\hline Baik & 1 & $10 \%$ \\
\hline Sedang & 9 & $90 \%$ \\
\hline Kurang & 0 & $0 \%$ \\
\hline Total & 10 & $100 \%$ \\
\hline
\end{tabular}

Table 2 Passing kelompok 2

\begin{tabular}{c|c|c}
\hline Kategori & Frekuensi & Presentase \\
\hline Baik & 4 & $40 \%$ \\
\hline Sedang & 6 & $60 \%$ \\
\hline Kurang & 0 & $0 \%$ \\
\hline Total & 10 & $100 \%$ \\
\hline
\end{tabular}

Table 3 Uji Paired T-Test Passing kelompok 1

\begin{tabular}{c|c|c|c|c}
\hline Mean & Sd & T-Score Terbesar & T-Score Terkecil & Sig (2-tailed) \\
\hline-6.000 & 4.137 & -3.041 & -8.959 & .001 \\
\hline
\end{tabular}

Table 4 Uji Paired T-Test Passing kelompok 2

\begin{tabular}{c|c|c|c|c}
\hline Mean & Sd & T-Score Terbesar & T-Score Terkecil & Sig (2-tailed) \\
\hline-7.200 & 3.425 & -4.750 & -9.650 & .000 \\
\hline
\end{tabular}

Diketahui bahwa nilai sig. (2-tailed) pada kelompok eksperimen 1 filanesia sebesar, $001<0,05$ maka dapat disimpulkan bahwa terdapat perbedaan yang nyata antara pretest,setelah menggunakan treatment filanesia dan posttest pada kelompok 1 Eksperimen filanesia.

Diketahui bahwa nilai sig. (2-tailed) pada kelompok eksperimen 2 controlling sebesar ,000< 0,05 maka dapat disimpulkan bahwa terdapat perbedaan yang nyata antara pretest,setelah menggunakan treatment filanesia dan posttest pada kelompok 2 eksperimen controlling.

Table 5 Uji Independent T-Test Passing kelompok 1 dan 2

\begin{tabular}{l|l|l|l|l|l|l}
\hline Hasil & $\begin{array}{l}\text { Mean } \\
\text { Difference }\end{array}$ & $\begin{array}{l}\text { Std. Error } \\
\text { Difference }\end{array}$ & Statistik Uji & $\begin{array}{l}\text { T-Score } \\
\text { Terbesar }\end{array}$ & $\begin{array}{l}\text { T-Score } \\
\text { Terkecil }\end{array}$ & $\begin{array}{l}\text { Sig (2- } \\
\text { tailed) }\end{array}$ \\
\hline $\begin{array}{l}\text { Equal } \\
\text { variances } \\
\text { assumed }\end{array}$ & -3.200 & 1.377 & -2.324 & -.307 & -6.093 & .032 \\
\hline $\begin{array}{l}\text { Equal } \\
\text { variances } \\
\text { not assumed }\end{array}$ & -3.200 & 1.377 & -2.324 & -.295 & -6.105 & .033 \\
\hline
\end{tabular}


Berdasarkan table Independent Simple T Test pada bagian Equality of Variances diketahui nilai Sig.(2-tailed) sebesar $0.032<0.05$ dengan demikian dapat disimpulkan ada perbedaan signifikan rata rata antara passing kelompok 1 dan kelompok 2 .

Table 6. Dribbling kelompok 1

\begin{tabular}{c|c|c}
\hline Kategori & Frekuensi & Presentase \\
\hline Baik & 1 & $10 \%$ \\
\hline Sedang & 9 & $90 \%$ \\
\hline Kurang & 0 & $0 \%$ \\
\hline Total & 10 & $100 \%$ \\
\hline
\end{tabular}

Table 7. Dribbling kelompok 2

\begin{tabular}{c|c|c}
\hline Kategori & Frekuensi & Presentase \\
\hline Baik & 5 & $50 \%$ \\
\hline Sedang & 5 & $50 \%$ \\
\hline Kurang & 0 & $0 \%$ \\
\hline Total & 10 & $100 \%$ \\
\hline
\end{tabular}

Table 8. Uji Paired T-Test Passing kelompok 1

\begin{tabular}{c|c|c|c|c}
\hline Mean & Sd & T-Score Terbesar & T-Score Terkecil & Sig (2-tailed) \\
\hline 7.700 & 4.057 & 10.602 & 4798 & .000 \\
\hline
\end{tabular}

Table 9. Uji Paired T-Test Passing kelompok 2

\begin{tabular}{l|c|l|l|l}
\hline Mean & Sd & \multicolumn{1}{|c|}{ T-Score Terbesar } & T-Score Terkecil & Sig (2-tailed) \\
\hline 9.000 & 4.830 & 12.456 & 5.544 & .000 \\
\hline
\end{tabular}

Diketahui bahwa nilai sig. (2-tailed) pada kelompok eksperimen 1 filanesia sebesar, $000<0,05$ maka dapat disimpulkan bahwa terdapat perbedaan yang nyata antara pretest,setelah menggunakan treatment filanesia dan posttest pada kelompok 1 eksperimen filanesia.

Diketahui bahwa nilai sig. (2-tailed) pada kelompok eksperimen 2 controlling sebesar ,000 < 0,05 maka dapat disimpulkan bahwa terdapat perbedaan yang nyata antara pretest,setelah menggunakan treatment filanesia dan posttest pada kelompok 2 eksperimen controlling.

Table 10. Uji Independent T-Test Passing kelompok 1 dan 2

\begin{tabular}{l|l|l|l|l|l|l}
\hline Hasil & $\begin{array}{l}\text { Mean } \\
\text { Difference }\end{array}$ & $\begin{array}{l}\text { Std. Error } \\
\text { Difference }\end{array}$ & $\begin{array}{l}\text { Statistik } \\
\text { Uji }\end{array}$ & $\begin{array}{l}\text { T-Score } \\
\text { Terbesar }\end{array}$ & $\begin{array}{l}\text { T-Score } \\
\text { Terkecil }\end{array}$ & $\begin{array}{l}\text { Sig (2- } \\
\text { tailed) }\end{array}$ \\
\hline $\begin{array}{l}\text { Equal variances } \\
\text { assumed }\end{array}$ & 1.300 & 1.098 & 1.184 & 3.607 & -1.007 & .252 \\
\hline $\begin{array}{l}\text { Equal variances } \\
\text { not assumed }\end{array}$ & 1.300 & 1.098 & 1.184 & 3.636 & -1.036 & .254 \\
\hline
\end{tabular}

Berdasarkan table Independent Simple T Test pada bagian Equality of Variances diketahui nilai Sig.(2-tailed) sebesar $0.252>0.05$ dengan demikian dapat disimpulkan tidak ada perbedaan signifikan rata-rata antara Dribbling kelompok 1 dan kelompok 2. 
Pengaruh Kurikulum Filosofi Sepak Bola Indonesia (Filanesia) Terhadap Kemampuan Dribbling Dan Passing Di Sekolah Sepak Bola Putra Mulyoharjo (Ps Puma) U-17 Kabupaten Jepara. Riki Candra setiawan

\section{KESIMPULAN}

Hasil penelitian setelah dilakukan Pretest dan Posttest pada ke dua kelompok eksperimen tehnik dasar sepakbola Passing dan Dribbling di Sekolah Sepakbola PS.Puma Mulyoharjo Kabupaten Jepara Usia 17 tahun dengan menggunakan kurikulum filosofi sepakbola Indonesia terjadi perubahan sighnifikan dan nyata. Dari test analisa data dengan menggunakan Paired Simple T-Test dan Independent T-Test.

\section{DAFTAR PUSTAKA}

Aditya, K. N. (2018). Pengaruh Latihan Small Side Games Dan Passing Kelompok Mengubah Posisi Terhadap Akurasi Passing Mendatar Pada Pemain Ssb Porma Kudus Ku-13 Tahun 2018 (Doctoral dissertation, Universitas Negeri Semarang).

Aprianova, F., \& Hariadi, I. (2017). Metode Drill Untuk Meningkatkan Teknik Dasar Menggiring Bola (Dribbling) Dalam Permainan Sepakbola Pada Siswa Sekolah Sepakbola Putra Zodiac Kabupaten Bojonegoro Usia 13-15 Tahun. Indonesia Performance Journal, 1(1).

Arwandi, J., \& Ardianda, E. (2018). Latihan Zig-Zag Run Dan Latihan Shuttle Run Berpengaruh Terhadap Kemampuan Dribbling Sepakbola. Jurnal Performa Olahraga, 3(01), 32-32.

Atiq, A. (2012). Tingkat Keterampilan Tehnik Dasar Sepakbola LPI SMP 3 Pontianak Tahun 2012. Media Ilmu Keolahragaan Indonesia, 2(1).

Dawud, V. W. G., \& Hariyanto, E. (2020). Survei Kondisi Fisik Pemain Sepakbola U 17. Sport Science and Health, 2(4), 224-231.

Emral, E., \& Tangkudung, J. A. (2015). Development Of Dribbling Basic Technique Skill Of Students Of Psts Tabing Padang Football School. Jipes-Journal Of Indonesian Physical Education And Sport, 1(1), 12-20.

Gardasevic, J., \& Bjelica, D. (2008). The Effects Of The Training In The Preparation Period On The Dribbling Speed With Fifteen Years Old Football Players. Strength and Conditioning Journal, 30, 2.

Irianto, S. (2010). Pengembangan Tes Kecakapan "David Lee" untuk Sekolah Sepak Bola (SSB) Kelompok Umur 14-15 Tahun.

Luxbacher, J. (1997). Sepakbola. PT RajaGrafindo.

Marta, I. A., \& Oktarifaldi, O. (2020). Koordinasi Mata-Kaki dan Kelincahan terhadap Kemampuan Dribbling Sepakbola. Gelanggang Olahraga: Jurnal Pendidikan Jasmani Dan Olahraga, 4(1), 114.

Mubarok, M. Z. (2019). Pengaruh Latihan Small Sided Games Mengunakan Metode Interval Terhadap Peningkatan Dribbling Pemain Sepakbola. Biormatika: Jurnal ilmiah fakultas keguruan dan ilmu pendidikan, 5(02), 144-149. 
Mubarok, M. Z., \& Mudzakir, D. O. (2020). Pengaruh Latihan Small Sided Games Terhadap Peningkatan Keterampilan Dribbling Pemain Sepakbola. Jurnal Pendidikan Olah Raga, 9(1), $28-40$.

Mubarok, M. Z., \& Ramadhan, R. (2019). Analisis Tingkat VO2Max Pemain Sepak Bola Darul Ma'arif Indramayu. Jurnal Kependidikan Jasmani dan Olahraga, 3(1), 39-45.

Mulyana, A. S. (2013). Analisis Kondisi Fisik dan Teknik Dasar Sepakbola Ekstrakurikuler Sepakbola SMAN 2 Ciamis (Doctoral dissertation, Universitas Pendidikan Indonesia).

Nugroho, W. (2015). Pengaruh latihan passing bervariasi posisi tetap dan berubah terhadap hasil akurasi short passing siswa ku-14 ssb apacinti tahun 2015 (Doctoral dissertation, Universitas Negeri Semarang).

Oktober, Y., \& Komarudin, M. A. (2012). Skripsi yang berjudul" Tingkat Keterampilan Bermain Sepakbola Siswa Peserta Ekstrakurikuler Sepakbola di SMA Negeri 1 Rembang Tahun.

Santoso, N. (2014). Tingkat Keterampilan Passing-Stoping Dalampermainan Sepakbola Pada Mahasiswa Pjkr Bangkatan 2013. Jurnal Pendidikan Jasmani Indonesia, 10(2).

Sequential, A. (2019). Pengaruh Latihan Long Passing Menggunakan Sasaran Berurutan Terhadap Ketepatan Long Passing Dalam Permainan Sepak Bola. Journal of SPORT, 3(2).

Tarju, T., \& Wahidi, R. (2017). Pengaruh Metode Latihan Terhadap Peningkatan Passing Dalam Permainan Sepak Bola. JUARA: Jurnal Olahraga, 2(2), 66-72.

Timo Scheunemann, (2005). Hakikat Passing Sepak Bola. Penerbit Kota

Yulianto, P. F. (2016). Perbedaan Pengaruh Pendekatan Pembelajaran Metode Bagian Dan Keseluruhan Terhadap Peningkatan Dribble Shooting Sepakbola Ditinjau Dari Koordinasi Mata-Kaki. (Studi Eksperimen Pada Mahasiswa Pembinaan Prestasi Sepakbola Fakultas Keguruan Dan Ilmu Pendidika. Jurnal Ilmiah SPIRIT, 16(1).

Yulianto, P. F. (2016). Perbedaan Pengaruh Pendekatan Pembelajaran Metode Bagian Dan Keseluruhan Terhadap Peningkatan Dribble Shooting Sepakbola Ditinjau Dari Koordinasi Mata-Kaki (Studi Eksperimen Pada Mahasiswa Pembinaan Prestasi Sepakbola Fakultas Keguruan Dan Ilmu Pendidika. Jurnal Ilmiah SPIRIT, 16(1). 